\title{
Partisipasi Masyarakat Sebagai Basis Kebijakan Penataan Ruang Publik dan Ruang Terbuka Hijau Kota yang Berkelanjutan
}

\author{
F.C. Susila Adiyanta \\ Fakultas Hukum, Universitas Diponegoro \\ susilafhundip@gmial.com.
}

\begin{abstract}
Development as an activity can affect and bring impact to the environment and the natural surroundings. Various urban development activities bring changes to the functions and land use of a region should be structured according to urban spatial planning, technical procedures, institutions, and legal institutions. Based on the focus of the study on community participation as a basis for sustainable urban public spatial and green spaces policy, the result of this nondoctrinal approach shows that the public spaces and green spaces of the city are an integral and inseparable part of the spatial city with the main function As a means of social interaction of urban communities, the heart of the ecosystem balance and the urban environment, as well as a form of expression of social values, ekonomo, culture and actualization of the faces of urban life. The recommendation of this research is the need of law enforcement by cracking down and imposing tough and severe sanctions to all those who are not paying attention even violating the regulation related to environmental aspect, such as green open space in settlement area.
\end{abstract}

Keywords: Public And Green Open Spatial Planning Policy, Community Participation

\begin{abstract}
Abstrak
Pembangunan sebagai suatu kegiatan dapat mempengaruhi dan membawa dampak terhadap lingkungan serta alam sekitarnya. Berbagai aktivitas pembangunan di perkotaan membawa perubahan atas fungsi dan peruntukan tanah pada suatu kawasan harus disusun berdasarkan perencanaan tata ruang kota, prosedur teknis, kelembagaan, maupun pranata hukum. Berdasarkan fokus kajian tentang partisipasi masyarakat sebagai basis kebijakan penataan ruang publik dan ruang terbuka hijau kota yang berkelanjutan, hasil penelitian dengan pendekatan non doktrinal ini menunjukkan bahwa ruang publik dan ruang hijau kota merupakan satu kesatuan dan bagian yang tidak terpisahkan dari tata ruang kota dengan fungsi utama sebagai sarana interaksi sosial masyarakat kota, jantung keseimbangan ekosistem serta lingkungan hidup kota, serta wujud ekspresi nilai-nilai sosial, ekonomo, budaya dan aktualisasi wajah kehidupan masyarakat kota. Rekomendasi penelitian ini adalah diperlukan penegakan hukum dengan menindak dan pengenaan sanksi yang tegas dan berat kepada semua pihak yang kurang memperhatikan bahkan melanggar peraturan terkait aspek lingkungan, seperti ruang terbuka hijau di kawasan permukiman.
\end{abstract}

Kata Kunci: Kebijakan Penataan Ruang Publik Dan Terbuka Hijau, Partisipasi Masyarakat 


\section{A. Latar Belakang Masalah}

Pembangunan adalah sebuah proses produksi dan konsumsi dimana materi dan energi diolah dengan mengunakan faktor produksi dan modal, mesin-mesin (capital), tenaga kerja (labour atau human resources ), dan bahan baku (natural resources). Dalam hal penyediaan bahan baku dan proses produksinya, kegiatan pembangunan dapat membawa dampak kepada lingkungan alam dan masyarakat sekitarnya, yang pada gilirannya akan berdampak pada keberlanjutan pembangunan itu sendiri ${ }^{1}$.

Pembangunan sebagai suatu kegiatan dapat mempengaruhi dan membawa dampak terhadap lingkungan serta alam sekitarnya. Sebagai langkah preventif atas resiko dan kemungkinan dampak yang terjadi, maka setiap kegiatan pembangunan harus membuat perencanaan dan antisipasinya berupa analisis mengenai dampak lingkungan (AMDAL). Demikia pula aktivitas pembangunan perumahan dalam suatu kawasan perkotaan yang membawa perubahan atas fungsi dan peruntukan tanah pada suatu kawasan, harus disusun berdasarkan mekanisme pemuatan kajian dampak lingkungan hidup secara formal dalam kaitannya dengan perencanaan tata ruang kota, prosedur teknis, kelembagaan, maupun pranata hukumnya ${ }^{2}$.

Ketersediaan ruang publik dan ruang terbuka hijau di dalam perencanaan tata ruang kota merupakan bagian dari aspek perlindungan lingkungan hidup yang tak dapat diabaikan begitu saja dari dampak kegiatan pembangunan. Demikian pula konsep pembangunan yang berwawasan lingkungan dan berkelajutan merupakan salah satu paradigma pembangunan yang menjadi tolok ukur kebijaksanaan pemerintah dalam pengambilan keputusan perencanaan tata ruang dan penatagunaan lahan di kawasan perkotaan ${ }^{3}$.

Dengan memggunakan metode empiris atau non doktrinal, artikel sebagai slah satu perspektif substantif dari penelitian ini hendak menjelaskan tentang praksis tata kelola ruang rubli dan ruang terbuka hijau yang berkelanjutan dengan basis prinsip-prinsip pembangunan berkelanjutan dan peran masyarakat.

\section{Rumusan Masalah}

Berangkat dari latar belakang permasalahan pesatnya pembangunan di kawasan perkotaan serta implikasinya terhadap lingkungan hidup yang meliputi pemukiman dan semua komponen yang saling terkait dengan ekosistem, tata ruang dan sosial kehidupan masyarakat, maka penting untuk melakukan riset dengan fokus tentang "Partisipasi Masyarakat sebagai Basis Kebijakan Penataan Ruang Publik dan Ruang Terbuka Hijau Kota yang Berkelanjutan.", dengan rumusan permasalahan sebagai berikut :

a) Apa prinsip-prinsip kebijakan pembangunan-khususnya tata kelola ruang publik dan ruang terbuka kawasan perkotaan- dengan melibatkan partisipasi masyarakat?

b) Apa landasan ideal bagi praksis kebijakan perencanaan dan tata kelola ruang publik dan ruang terbuka hijau yang berkelanjutan?

c) Bagaimana peran kelembagaan publik dalam tata kelola tata kelola ruang publik dan ruang terbuka hijau yang berkelanjutan?

\section{B. Pembahasan}

1. Prinsip-prinsip Pembangunan Berkelanjutan dan Peran Masyarakat

\footnotetext{
${ }^{1}$ Daniel Murdiarso, CDM, Mekanisme Pembangunan Bersih, Penerbit Buku Kompas, Jakarata 2003, hlmn.143

2 Emil Salim, Pembangunan Berwawasan Lingkungan, LP3ES, Jakarta, 2003, hlmn. 98.

3 UU No. 25 Tahun 2000
} 
Konsep pembangunan berkelanjutan (sustainable development) ini pertama kali dicetuskan oleh World Commision on Environment and Development (Komisi Dunia untuk Lingkungan dan Pembangunan). Di dalam deklarasi tersebut yang dimaksud dengan pembangunan berkelanjutan (sustainable development) adalah sebagai suatu pendekatan pembangunan untuk memenuhi kebutuhan generasi masa kini tanpa mengurangi kemampuan generasi masa depan/mendatang untuk memenuhi kebutuhannya sendiri ${ }^{4}$. Dalam sidangnya yang diadakan di Tokyo pada tahun 1987, WECD telah menghasilkan rumusan dan prinsipprinsip dasar pembangunan yang berkelanjutan (sustainable development) yang dikenal sebagai deklarasi Tokyo.

Ada tiga prinsip utama pembangunan berkelanjutan (sustainable development). Prinsip-prinsip pembangunan berkelanjutan secara singkat dapat disebutkan sebagai berikut : Pertama, prinsip demokrasi. Prinsip ini menjamin agar pembangunan dilaksanakan sebagai perwujudan kehendak bersama seluruh rakyat demi kepentingan bersama seluruh rakyat. Dalam prinsip demokrasi ini ada beberapa aspek penting yatitu bahwa agenda utama pembangunan adalah agenda rakyat demi kepentingan rakyat, partisipasi masyarakat dalam merumuskan dan mengimplementasikan pembangunan merupakan keharusan moral dan politik, keharusan adanya akses informasi yang jujur dan terbuka tentang agenda pembangunan serta adanya akuntabilitas publik tentang agenda pembangunan, proses perumusan kebijakan dan implementasi pembangunan. Kedua, prinsip keadilan. Prinsip ini pada dasarnya menjamin bahwa semua orang dan kelompok masyarakat memperoleh peluang yang sama untuk ikut dalam proses pembangunan dan kegiatan-kegiatan produktif serta ikut dalam menikmati hasil-hasil pembangunan. Ketiga, prinsip keberlanjutan. Prinsip ini mengharuskan pengambil kebijakan publik untuk merancang agenda pembangunan dalam dimensi visioner jangka panjang, untuk melihat dampak pembangunan baik positif maupun negative dalam segala aspeknya, tidak hanya dalam dimensi jangka pendek ${ }^{5}$.

Ketiga prinsip tersebut menjamin agar ketiga aspek pembangunan hanya mungkin dicapai kalau ketiga prinsip dasar ini dioperasionalkan sebagai sebuah politik pembangunan. Prinsip-prinsip tersebut juga mengharuskan untuk memilih alternaitif pembangunan yang lebih hemat sumber daya dan mampu mensinkronkan aspek konservasi dengan aspek pemanfaatan secara arif. Dengan demikian prinsip-prinsip ini sejalan dengan kenyataan bahwa sumber daya ekonomi terbatas, aspek sosial budaya dan lingkungan hidup adalah aspek yang berdimensi jangka panjang, dan bahwa pembangunan berlangsung dalam ruang ekosistem yang mempunyai interaksi rumit ${ }^{6}$.

\section{Kebijakan Pembangunan Ruang Publik dan Ruang Terbuka Hijau Perkotaan: Keseimbangan antara Hak dan Kewajiban sebagai Nilai Dasar bagi Partisipasi Publik}

Dalam perencanaan penataan ruang dan penatagunaan lahan sebagai bagian dari pengembangan kawasan perkotaan, pertimbangan aspek integrasi dan keberlanjutan dengan rencana tata ruang kota merupakan salah satu faktor yang harus menjadi bahan pertimbangan pemerintah maupun perusahaan pengembang. Salah satu konsep pembangunan kawasan perkotaan diantaranya adalah upaya penyempurnaan pengembangan kelembagaan dan peningkatan kapasitas pengelolaan kota, pemantapan sistem dan standar pelayanan publik, peningkatan kemitraan pemerintah, masyarakat dan swasta dalam pembangunan dan

\footnotetext{
${ }^{4}$ Eddy Ihut Siahaan, Filosofi Perencanaan Pembangunan Kota Sesuai Paradigma Baru Indonesia: Hakikat IImu Untuk Pemberdayaan dan Peningkatan Peranserta Masyarakat, www.google.com. Jakarta 20005

5 A. Sonny Keraf, Etika Lingkungan, Penerbit Buku Kompas, Jakarta, 2002, hlmn. 175-182.

6 Ibid, hlmn. 180.
} 
pengembangan kawasan kota, peningkatan fungsi kawasan kota serta pengembangan wilayah yang terintegrasi dalam suatu pengembangan jaringan pelayanan perkotaan yang mendukung alur produksi, koleksi dan distribusi antar kota, antar wilayah, dan antar perkotaan dengan pedesaan ${ }^{7}$.

Perencanaan pembangunan perkotaan oleh John Friedman dideskripsikan dalam arti luas, yaitu sebagai upaya menjembatani pengetahuan ilmiah dan teknik terhadap tindakantindakan dalam kekuasaan publik yang menyangkut proses pengarahan dan transformasi sosial. Pembangunan perkotaan diklasifikasikan atas beberapa sistem, yaitu $:^{8}$

1. Perencana sebagai reformasi sosial. Dalam sistem perencanaan ini peran pemerintah sangat dominant dengan system perencanaan persifat terpusat ditujukan ke masayarakat (top down), politik pengambilan kebijakan bersifat terbatas dan berjenjang.

2. Perencanaan sebagai analisis kebijakan. Dalam sistem ini pemerintah bersama stakeholder memutuskan persoalan dan menyusun alternatiff kebijakan, sistem ini bersifat desentralisasi, terbuka terhadap partisipasi masyarakat, dan politik kebijakan yang terbuka dan ilmiah.

3. Perencanaan sebagai pembelajaran sosial. Sistem ini bersifat learning by doing, pelimpahan kewenangan lebih bersifat desentralisasi, mengutamakan partisipasi rakyat (bottom up), pemerintah bertindak sebagai fasilitator berdasarkan kebijakan politik yang bersifat terbuka.

4. Perencanaan sebagai transformasi sosial, yaitu merupakan kristalisasi politik yang didasarkan pada ideology "koletivisme komuterian".

Berdasarkan beberapa sistem perencanaan pembangunan sebagaimana disebutkan di atas, partisipasi masyarakat merupakan suatu proses yang memberi peluang dan kesempatan pada masyarakat dalam perencanaan pembangunan. Tujuan dari peranserta masyarakat yang ingin dicapai pada prinsipnya harus dikondisikan oleh pihak pemerintah sebagai pihak yang mempunyai kewenangan dalam pengambilan keputusan. Peranserta individu dan masyarakat secara bebas dapat terjadi bila individu-individu dalam masyarakat melibatkan diri secara sukarela dalam suatu kegiatan partisipatif tertentu tanpa harus mendapat intervensi dari pemerintah.

Donald Pergult menyatakan bahwa ada beberapa faktor yang dapat mendorong dan menjadi penghambat peranserta masyarakat dalam perencanaan penataan ruang kota, yaitu : ${ }^{9}$

1. Partisipasi dalam proses perencanaan lokal umumnya dimulai sangat terlambat, yaitu setelah rencana (the real planning directions) telah selesai disusun, sehingga masyarakat akhrinya hanya mempertanyakan hal-hal yang bersifat detail.

2. Partisipasi komunitas yang syngguh-sungguh bersifat sangat sedikit, selai itu hanya mengenai isu-isu besar seperti pertumbuhan pembangunan kota.

3. Ketika partisipasi tersebut benar-benar diinginkan, terlalu sedikit masyarakat yang terorganisasi atau terstruktur secara mapan efwktif mengajukan masukan.

4. Pemerintah pusat maupun pemerintah local, jika memang menghendaki, sebenarnya mampu membuat keputusan-keputusan secara rahasia atau dengan menyediakan waktu yang tidak memadai untuk diskusi public.

\footnotetext{
${ }^{7}$ UU No. 25 Tahun 2000.

8 Emil Salim, Ibid.

9 Bappeda DKI dan P3WK ITB, Peranserta Masyarakat dalam Perencanaan Tata Ruang dan Pembangunan, Jakarta, 2001, hlmn. 67
} 
5. secara umum komunitas tidak memiliki sumber daya yang memadai dalam hal waktu, keahlian atau ruang untuk membuat aspirasi mereka didengar dan diterima secara efektif.

Berdasarkan atas beberapa faktor yang dapat mempengaruhi partisipasi masyarakat dalam perencanaan ruang kota, maka kemauan dan iktikad baik pemerintah merupakan salah satu pendukung iklim yang kondusif bagi masyarakat, tanpa adanya keterbukaan pemerintah sebagai pihak yang mempunyai kewenangan, maka berbagai kendala tersebut semakin lebih menutup kemungkinan interaksi antara masyarakat dan pemerintah dalam perencanaan dan penataan ruang kota.

Selama ini peran serta masyarakat dalam ajang penataan ruang terformat dalam bentuk partisipasi yang relatif pasif. Dengan ditetapkannya Undang-Undang 26 Tahun 2007 tentang Penataan Ruang yang menggantikan undang-undang yang ditetapkan tahun 1992, paradigma ini telah berubah. Dalam UU No. 26 Tahun 2007 tentang penataan Ruang disebutkan bahwa peluang masyarakat untuk berkiprah dalam penataan ruang telah terbuka lebar, tidak hanya terbatas "ikut berpartisipasi", melainkan lebih mengarah ke "peran aktif" pada setiap tahapan penyelenggaraan penataan ruang, mulai dari pengaturan, pembinaan, pelaksanaan, hingga pengawasan. Namun sayang, sudah setahun UU No. 26 Tahun 2007 ini diberlakukan, kiprah dan gaungnya masih belum nyata.

Kondisi yang demikian ini karena penataan ruang masih belum dikenal dan dipahami oleh kebanyakan masyarakat secara utuh. Karena itu, sosialisasi dan apresiasi UU No. 26 Tahun 2007 tidak boleh berhenti dan harus terus dilakukan secara kontinyu, serta tidak hanya terbatas kepada aparat pemerintah yang mengemban kewenangan untuk menata ruang, namun juga kepada masyarakat luas, paling tidak sosialisasi dan apresiasi tentang ketentuan mengenai hak dan kewajiban masyarakat dalam penataan ruang. Melalui sosialisasi dan apresiasi, diharapkan masyarakat dapat lebih mengenal dan memahami hak dan kewajibannya dalam penataan ruang yang diselenggarakan oleh pemerintah. Pengenalan dan peningkatan pemahaman publik atas penataan ruang adalah suatu proses panjang yang diharapkan dapat mendorong terbentuknya "sikap peduli" pada mulanya,hingga "peran aktif' yang melembaga sampai pada unit masyarakat terkecil.

Pemerintah telah menetapkan enam hak setiap orang dalam penataan ruang disamping empat kewajiban dalam pemanfaatan ruang. Hak dan kewajiban masyarakat perlu diwujudkan secara seimbang. Masyarakat tidak selayaknya selalu menuntut haknya tanpa diimbangi dengan penunaian kewajibannya. Demikian juga sebaliknya, pemerintah kurang bijak bila selalu menuntut masyarakat untuk menunaikan kewajibannya tanpa memberi kemudahan agar masyarakat dapat memperoleh haknya. Keduanya harus seimbang. Dalam pemanfaatan ruang, masyarakat mempunyai kewajiban untuk menaati rencana tata ruang (RTR) yang telah ditetapkan (di-Perda-kan). Namun, bagaimana bisa masyarakat menunaikan kewajibannya tersebut bila masyarakat tidak mengetahui RTR yang harus ditaatinya tersebut. Karenanya, masyarakat perlu diberi akses terhadap RTR, dan idealnya masyarakat juga diberi peluang agar terlibat secara aktif (ikut berperan) dalam proses penyusunan RTR.

Masyarakat yang sadar tata ruang dan kemudian memanfaatkan ruang sesuai dengan izin pemanfataan ruang (IPR) yang diberikan oleh pejabat yang berwenang, serta mematuhi segala ketentuan dan persyaratan yang telah ditetapkan dalam IPR tersebut, maka yang bersangkutan semestinya diberikan haknya untuk menikmati pertambahan nilai ruang dan memperoleh penggantian yang layak atas aktivitas pembangunan yang sesuai dengan rencana yang telah ditetapkan dalam RTR. Demikian pula halnya, bila masyarakat yang sadar dan peduli terhadap tata ruang disekitarnya, menemukan adanya indikasi pelanggaran terhadap RTR, lantas 
mengkonfirmasi temuannya tersebut dan terbukti terjadi ketidak-sesuaian pemanfaatan ruang dengan RTR, maka wajar bila masyarakat menuntut pembatalan izin dan penghentian pembangunan, serta melakukan gugatan ganti kerugian atas pemanfaatan ruang yang tidak sesuai dengan RTR, termasuk bila ada masyakarat yang tidak memenuhi kewajiban untuk memberi akses terhadap ruang publik (public space). Pemerintah dalam hal ini berkewajiban untuk memberikan akses seluas-luasnya agar masyarakat dapat memperoleh haknya.

\section{Partisipasi Kelembagaan Masyarakat : Kontribusi dalam Menata Ruang Publik dan Ruang Terbuka Hijau}

Kelembagaan di masyarakat ada yang memang sengaja dibentuk oleh pemerintah, namun ada juga yang dibentuk atas inisiatif sekelompok masyarakat yang kemudian ditetapkan dengan status hukum. Kelembagaan semacam ini dikategorikan sebaga lembaga formal. Sebut saja lembaga formal di masyarakat yang dibentuk oleh pemerintah yang merepresentasikan suatu kelompok masyarakat, seperti Kelompok Dasa Wisma dan Rukun Tetangga (RT) sebagai unit terkecil, kemudian Rukun Warga (RW), atau lembaga formal setara lainnya yang pembentukannya didasari oleh hukum adat. Lembaga ini dibentuk untuk tujuan memberikan pelayanan administratif pemerintahan, dan mendukung program-program pembangunan yang telah dicanangkan oleh pemerintah setempat.

Peran lembaga yang tumbuh dan berasal dari masyarakat dalam penyelenggaraan penataan ruang, memelihara lingkungan, dan menata ruang terbuka hijau sangat bergantung pada seberapa besar anggota masyarakat mengenal dan memahami tata ruang. Kiprah lembaga ini dalam mewujudkan cita-cita penyelenggaraan penataan ruang masih terkendala oleh tingkat pemahaman masyarakat umum mengenai tata ruang yang relatif belum memadai, sehingga gerak-langkah lembaga formal ini masih belum seperti yang diharapkan dalam UU 26/2007. Umumnya, RT dan RW dalam aktualisasi keseharian masih jauh dari upaya perwujudan ruang yang aman, nyaman, produktif dan berkelanjutan.

Kemudian, sekelompok masyarakat yang digerakkan oleh aktor-aktor yang peduli dan memang "memahami" tata ruang, mulai tumbuh bak jamur sejak tahun 2002, terutama di masyarakat perkotaan yang mulai merasakan dampak buruk dari kesemrawutan tata ruang di sekitarnya. Banjir yang selalu melanda Ibu Kota Negara, Jakarta misalnya, telah menyita perhatian semua pihak, termasuk Ditjen Penataan Ruang sebagai aktor penentu kebijakan tata ruang. Awalnya, kelompok masyarakat yang merepresentasikan pernaserta masyarakat kota terkait dengan persoalan banjir dan bencana alam yang terjadi dan dialami dalam beberapa tahun yang lalu ini dibentuk oleh Departemen Permukiman dan Prasarana Wilayah (Departemen Pekerjaan Umum - sekarang) sebagai respon atas terjadinya berbagai bencana yang diakibatkan oleh adanya pelanggaran peruntukan dan pemanfaatan ruang.

\section{Simpulan}

Berdasarkan latar belakang dan uraian pembahasan tentang permasalahan kota, fungsi, peruntukan dan urgensi keberadaan serta ketersediaan ruang publik dan ruang terbuka hijua kota, berikut ini beberapa simpulan dan saran yang dapat penulis sampaikan, yaitu:

1. Ketersediaan ruang publik dan ruang terbuka hijau (RTH) merupakan satu kesatuan dan bagian yang tidak terpisahkan dari tata ruang kota.

2. Ruang publik dan ruang hijau kota selain mempunyai fungsi utama bagi interaksi sosial masyarakat kota dan jantung keseimbangan ekosistem serta lingkungan hidup kota, juga 
mempunyai fungsi strategis sebagai wujud ekspresi nilai-nilai sosial, ekonomi, budaya dan aktualisasi wajah kehidupan masyarakat kota.

3. Tanggung jawab pengelolaan, peruntukan, dan pemanfaatan ruang publik dan ruang terbuka hijau secara berkelanjutan dapat dilakukan secara optimal apabila bersinergi antara pemerintan kota, swasta dan masyarakat.

\section{Saran}

1. Realiasasi pengelolaan, peruntukan, dan pemanfaatan ruang publik dan ruang terbuka hijau dan berkelanjutan dapat dilakukan secara formal dan secara informal oleh pemerintah kota dengan dukungan pihak swasta dan masyarakat, dengan cakupan keterlibatan masyarakat secara luas mulai dari individu, keluarga, hingga pada lembaga masyarakat, yatu: rukun tetangga, rukun warga, hingga instansi-instansi pemerintah.

2. Kebijakan dan pengaturan pembangunan kawasan kota yang membawa perubahan, peralihan fungsi dan peruntukan ruang publik dan ruang terbuka hijau harus berdasarkan rencara tata ruang kota. Kebijakan pemerintah, kegiatan swasta, dan masyarakat yang membawa dampak bagi perubahan fungsi dan peruntukan ruang dan lahan kota pada dasarnya harus memperhatikan aspek lingkungan selain aspek ekonomi dan sosial.

3. Untuk menjaga terwujudnya konsitensi serta keberlanjutan fungsi dan peruntukan ruang publik dan ruang terbuka hijau yang sesuai dengan rencana pembangunan dan tata ruang kota, diperlukan penegakan hukum dengan menindak dan pengenaan sanksi yang tegas dan berat kepada semua pihak yang kurang memperhatikan bahkan melanggar peraturan terkait aspek lingkungan, seperti ruang terbuka hijau di kawasan permukiman.

\section{Daftar Pustaka}

Achmad Soebana, 1998, Adaptasi Pelayanan Ijin Investasi Terhadap Perubahan Lingkungan, Citra Aditya Bhakti, Bandung

Achmad Erani Yustika, 2000, Industrialisai Pinggiran, Pustaka Pelajar, Yogyakarta

B. Arief Sidharta (Et.Al), 1998, Butir-Butir Gagasan Tetang Penyelenggaraa Hukum dan Pemerintahan Yang Layak, Citra Aditya Bhakti, Bandung

BN. Marbun, 1998, kota Indonesia Masa Depan, Masalah dan Prospek, Penerbit Erlangga, Jakarta

Dunkerley, H.B., Urban Land Policy : Issues and Opportunities. Washington D.C.: Oxford University Press, 1983.

Daud M. Silalahi, Hukum Lingkungan Dalam Sistem Penegakan Hukum Lingkungan Indonesia, Alumni, Bandung, 1998

Daniel Mudiarso, CDM, Mekanisme Pembangunan Bersih, Penerbit Buku Kompas, Jakarta 2003

Djenal Hoesien Koesoemahatmadja, Pokok-Pokok Hukum Tata Usaha Negara I, Citra Aditya Bhakti, Bandung, 1990

Emil Salim, Pembangunan Berwawasan Lingkungan, LP3ES, Jakarta 1993

Eko Budiharjo, Sejumlah Masalah Pemukiman Kota, Penerbit Alumni, Bandung, 1998

Miriam Budiardjo, Dasar-Dasar Ilmu Politik, Penerbit Gramedia, Jakarta, 1987

Otto Soemarwoto, Ekologi, Lingkungan Hidup dan Pembangunan, Gadjahmada University Press, Yogyakarta, 1997

Analisis Mengenai Dampak Lingkungan, Gadjahmada University Press, Yogyakarta, 1997 
Philipus M. Hajon, Penegakan Hukum Administrasi Dalam Pengelolaan Lingkungan Hidup, Citra Aditya Bhakti, Bandung 1998

PJM Nas, Kota di Dunia Ketiga, Suatu Pengantar Sosiologi Kota, Bharata Karya, Jakarta, 1998

Pontoh, Nia. dan Kustiawan, Iwan, Pengantar Perencanaan Perkotaan. Penerbit ITB. Bandung, 2009.

Purnomohadi, N., Ruang Terbuka Hijau Sebagai Unsur Utama Tata Ruang Kota. Jakarta: Direktorat Jenderal Penataan Ruang Departemen Pekerjaan Umum, 2006.

Bappeda DKI dan P3WT ITB, Peranserta Masyarakat Dalam Perencanaan Tata Ruang dan Pembangunan, Jakarta, 2001

Hairi Hadi, Strategi Pembangunan Kota-Kota Dalam Mewujudkan Kesatuan Ekonomi Nasional, Majalah Prisma No. 1 Tahun 1998

Philipus M. Hajon, Penegakan Hukum Administrasi dalam Pengelolaan Lingkungan Hidup, Makalah Seminar Lingkungan Hidup, FH Uii, Yogyakarta, Tanggal 26 Februari 1998

, UU No. 23 Tahun 1997 dan Penegakan Hukumnya Ditinjau Dari Aspek Hukum Administrasi, Makalah Seminar Nasional Kajian Dan Sosialisasi Uu No. 23 Tahun 1997 Tentang Pengelolaan Lingkungan Hidup, Fh Undip, Semarang, Tanggal 21 Februari 1998

Sjachran Basah, Sistem Perijinan Sebagai Instrument Pengendali Lingkungan Hidup, KLH Bekerjasama Dengan Mandate Compliance And Enforcement Program Bappedal, Jakarta, Tanggal 1-2 Mei 2001

\section{Perundang-undangan}

UU No. 5 Tahun 1960 tentang Peraturan Dasar Pokok-Pokok Agraria

UU No. 4 Tahun 1992 tentang Perumahan dan Permukiman

Undang-Undang No. 23 Tahun 1997 tentang Pengelolaan Lingkungan Hidup

UU No. 26 Tahun 2007 tentang Penataan Ruang

Peraturan Pemerintah No. 63 Tahun 2002 tentang Hutan Kota

Peraturan Pemerintah No. 16 Tahun 2004 tentang Penatagunaan Tanah

Instruksi Menteri Dalam Negeri No. 14 Tahun 1998. Penataan Ruang Terbuka Hijau Di Wilayah Perkotaan.

Peraturan Menteri Pekerjaan Umum No. 05/PRT/M/2008 tentang pedoman penyediaan dan Pemanfaatan Ruang terbuka Hijau di Kawasan Perkotaan. 